\title{
Apolipoprotein E Genotype Regulates Amyloid- $\beta$ Cytotoxicity
}

\author{
Micha M. M. Wilhelmus, ${ }^{1,2}$ Irene Otte-Höller, ${ }^{2}$ Judianne Davis, ${ }^{3}$ William E. Van Nostrand, ${ }^{3}$ Robert M. W. de Waal, ${ }^{2}$ and \\ Marcel M. Verbeek ${ }^{1,2}$ \\ Departments of ${ }^{1}$ Neurology and ${ }^{2}$ Pathology, Radboud University Nijmegen Medical Center, 6500 HB Nijmegen, The Netherlands, and ${ }^{3}$ Department of \\ Medicine, Health Sciences Center, Stony Brook University, Stony Brook, New York 11794-8153
}

The $\epsilon 4$ allele of apolipoprotein $\mathrm{E}$ ( $\mathrm{ApoE}$ ) is a risk factor for Alzheimer's disease (AD), whereas the $\epsilon 2$ allele may be relatively protective. Both alleles are risk factors for cerebral amyloid angiopathy (CAA)-related hemorrhages. CAA is associated with degeneration of smooth muscle cells and pericytes. Previously, we described that synthetic amyloid- $\beta_{1-40}$ peptide $\left(\mathrm{A} \beta_{1-40}\right)$ with the ${ }^{22} \mathrm{Glu} \rightarrow \mathrm{Gln}$ "Dutch" mutation caused pericyte death in vitro by a mechanism that involves $\mathrm{A} \beta$ fibril-like assembly at the cell surface. It is known that ApoE binds to $\mathrm{A} \beta$ and may modify its biological activities. In the present study, we evaluated the effect of $A p o E$ on $A \beta$-mediated toxicity of cerebrovascular cells. We observed that cultured cells with an $\epsilon 4 / \epsilon 4$ genotype were more vulnerable to $\mathrm{A} \beta$ than cultures with an $\epsilon 3 / \epsilon 3$ or $\epsilon 3 / \epsilon 4$ genotype. The one cell culture with the $\epsilon 2 / \epsilon 3$ genotype was relatively resistant to $\mathrm{A} \beta$ compared with other cultures. Furthermore, we observed a dose-dependent protective effect of native ApoE against $\mathrm{A} \beta$-mediated toxicity of cerebrovascular cells and, in addition, ApoE $\epsilon 2 / \epsilon 3$ cells secreted more ApoE protein compared with cells with other ApoE genotypes, in particular, compared with $\epsilon 4 / \epsilon 4$ cells. Thus, the disparity between ApoE genotype and $\mathrm{A} \beta$-mediated toxicity might be related to differences in the cellular capacity to secrete ApoE. The present data suggest that one mechanism by which $\mathrm{ApoE}$ may alter the risk for $\mathrm{AD}$ is a genotype-dependent regulation of $\mathrm{A} \beta$ cytotoxicity, possibly via variations in its secretion levels, whereby extracellular ApoE may bind to $A \beta$ and thereby modify $A \beta$-mediated cell death.

Key words: apolipoprotein E; Alzheimer's disease; amyloid- $\beta$ protein; cerebrovascular cells; CAA; cytotoxicity

\section{Introduction}

Senile plaques (SPs) and cerebral amyloid angiopathy (CAA) are two of the neuropathological hallmarks of Alzheimer's disease $(\mathrm{AD})$. The amyloid- $\beta$ protein $(\mathrm{A} \beta)$, which consists of $40-42$ amino acids, is the major constituent of both SPs and CAA. Apolipoprotein $\mathrm{E}$ (ApoE) has been identified as a major risk factor for the sporadic late-onset form of $\mathrm{AD}$. The ApoE gene has three alleles $(\epsilon 2, \epsilon 3$, and $\epsilon 4)$, the most frequent of which is the $\epsilon 3$ allele. Inheritance of one or two copies of the $\epsilon 4$ allele is associated with a dose-dependent increased risk for $\mathrm{AD}$ and an earlier age of onset of AD (Corder et al., 1993; Saunders et al., 1993), although individuals homozygous for $\epsilon 4$ may reach a high age without cognitive impairment (Henderson et al., 1995). On the contrary, the $\epsilon 2$ allele seems to have a protective effect against AD (Corder et al., 1994). Surprisingly, however, both the $\epsilon 2$ and the $\epsilon 4$ alleles

\footnotetext{
Received 0ct. 11, 2004; revised Feb. 21, 2005; accepted Feb. 23, 2005.

This work was supported by grants from the Internationale Stichting Alzheimer Onderzoek (01506) and The Netherlands Organization for Scientific Research "Vidi-Vernieuwingsimpuls" (917.46.331) and by National Institutes of Health Grant NS35781 (W.E.V.N.). We thank G. Steenbergen-Spanjers for performing the ApoE genotyping; Dr. A. J. W. Zendman for his assistance with Northern blot analysis; Drs. P. Wesseling and B. Küsters for neuropathological diagnosis; and Drs. R. Koopmans, J. H. M. Cox-Claessens, and G. Woestenburg (Psychogeriatric Centers "Joachim en Anna" and "Margriet," Nijmegen, The Netherlands) for their cooperation in the rapid autopsy protocol.

Correspondence should be addressed to M. M. M. Wilhelmus, Department of Pathology, Radboud University Nijmegen Medical Centre, PA 437, P.0. Box 9101, 6500 HB Nijmegen, The Netherlands. E-mail: m.wilhelmus@pathol.umcn.nl.

DOI:10.1523/JNEUROSCI.4213-04.2005

Copyright $\odot 2005$ Society for Neuroscience $\quad$ 0270-6474/05/253621-08\$15.00/0
}

are associated with an increased risk for CAA or CAA-related hemorrhages (Greenberg et al., 1996, 1998; Premkumar et al., 1996; Nicoll et al., 1997).

Inheritance of one or two copies of the ApoE $\epsilon 4$ allele is associated with a higher load of SPs and CAA (Schmechel et al., 1993; Premkumar et al., 1996). In vitro studies have shown that ApoE is able to bind to A $\beta$ (Strittmatter et al., 1993; Pillot et al., 1999); native ApoE3 binds A $\beta$ more efficiently than ApoE4 (LaDu et al., 1994). ApoE may also accelerate the formation of $\mathrm{A} \beta$ fibrils (Strittmatter et al., 1993; Sanan et al., 1994; Wisniewski et al., 1994). In mice transgenic for human amyloid precursor protein (APP) and deficient in ApoE, the amount of amyloid, but not that of $\mathrm{A} \beta$ immunoreactivity, was strongly reduced compared with transgenic APP/ApoE ${ }^{+/+}$mice (Bales et al., 1999), suggesting that ApoE plays a critical role in facilitating $A \beta$ deposition. In contrast to these studies, early $\mathrm{A} \beta$ deposition is suppressed in mice transgenic for both APP and human ApoE on an ApoE knock-out background (Holtzman et al., 1999). These results show that the role of ApoE and its specific isoforms in $\mathrm{A} \beta$ fibrillogenesis, deposition, or clearance still remains unclear.

Previously, we described the toxicity of various $\mathrm{A} \beta$ peptides toward cultures of human brain cerebrovascular smooth muscle cells (SMCs) and human brain pericytes (HBPs) (Davis-Salinas et al., 1995; Davis and Van Nostrand, 1996; Verbeek et al., 1997). We demonstrated that nonaggregated wild-type $\mathrm{A} \beta_{1-42}$ and $\mathrm{A} \beta_{1-40}$ carrying the $\mathrm{Glu} \rightarrow$ Gln mutation at position 22 of $\mathrm{A} \beta$, as 
Table 1. Overview of the source of HBP and SMC cell cultures

\begin{tabular}{|c|c|c|c|c|c|c|c|c|c|c|c|}
\hline Number & Diagnosis & Grade (Braak) & Grade (CERAD) & CAA grade & Cell type & PMI (h) & ApoE & Age & Gender & Cause of death & Vascular risk factors \\
\hline 1 & Control & $\|$ & ++ & - & $\mathrm{HBP} / \mathrm{SMC}$ & 5 & $2 / 3$ & 84 & $\mathrm{~F}$ & Cardiac failure & Atherosclerosis \\
\hline 2 & $A D$ & $\mathrm{VI}$ & +++ & - & HBP & 4 & $3 / 3$ & 94 & $\mathrm{~F}$ & Respiratory insufficiency & Atherosclerosis \\
\hline 3 & $A D$ & $\mathrm{Vl}$ & +++ & +++ & $\mathrm{HBP}$ & 4 & $3 / 3$ & 81 & $\mathrm{~F}$ & Cardiac failure & None \\
\hline 4 & $A D$ & $\mathrm{Vl}$ & +++ & +++ & $\mathrm{HBP} / \mathrm{SMC}$ & 3 & $3 / 3$ & 75 & M & Pneumonia & Atherosclerosis \\
\hline 5 & Control & 0 & 0 & - & $\mathrm{HBP} / \mathrm{SMC}$ & 4 & $3 / 3$ & 84 & $\mathrm{~F}$ & Pneumonia & Atherosclerosis \\
\hline 6 & Control & 0 & 0 & - & SMC & 6 & $3 / 3$ & 71 & $F$ & Ruptured aortic aneurysm & Atherosclerosis \\
\hline 7 & $A D$ & V & +++ & + & SMC & 6 & $3 / 3$ & 87 & $\mathrm{~F}$ & Bronchopneumonia & Atherosclerosis \\
\hline 8 & $A D / P D$ & V & +++ & +++ & SMC & 4 & $3 / 4$ & 91 & $\mathrm{~F}$ & Pneumonia & Atherosclerosis \\
\hline 9 & $A D$ & V & +++ & - & $\mathrm{HBP}$ & 5 & $3 / 4$ & 84 & M & Cardiac failure & Atherosclerosis \\
\hline 10 & Control & III & ++ & - & $\mathrm{HBP} / \mathrm{SMC}$ & 4 & $3 / 4$ & 83 & $\mathrm{~F}$ & Ruptured aortic aneurysm & Atherosclerosis \\
\hline 11 & $A D$ & $\mathrm{Vl}$ & +++ & ++ & $\mathrm{HBP} / \mathrm{SMC}$ & 3 & $3 / 4$ & 89 & $\mathrm{~F}$ & Pneumonia & Atherosclerosis \\
\hline 12 & $A D$ & $\mathrm{Vl}$ & ++ & +++ & $\mathrm{HBP}$ & 5 & $4 / 4$ & 83 & $F$ & Sepsis & Atherosclerosis \\
\hline 13 & $A D$ & $\mathrm{Vl}$ & +++ & +++ & $\mathrm{HBP} / \mathrm{SMC}$ & 3 & $4 / 4$ & 69 & M & Unknown & Atherosclerosis \\
\hline
\end{tabular}

F, Female; M, male; PD, Parkinson's disease; PMI, postmortem interval in hours. Grading of AD (Braak and CERAD scores) and CAA was performed as described in Materials and Methods.

in hereditary cerebral hemorrhage with amyloidosis-Dutch type, caused degeneration of cultured SMCs and HBPs. Either cell type secreted significant amounts of ApoE (Verbeek et al., 1999). Given the well described interactions between ApoE and $\mathrm{A} \beta$, we investigated whether endogenously produced ApoE could interfere in an isoform-dependent manner with the $A \beta$-mediated cytotoxicity toward cultured human cerebrovascular cells. Therefore, in this study, we performed a comparative analysis of the cytotoxic effect of $\mathrm{A} \beta$ on cultures of HBPs and SMCs with different ApoE genotypes.

\section{Materials and Methods}

Reagents. $\mathrm{A} \beta$ with the "Dutch" mutation $\left(22 \mathrm{Glu} \rightarrow \mathrm{Gln} ; \mathrm{D}-\mathrm{A} \beta_{1-40} ; 89 \%\right.$ pure) was purchased from Biosource (Etten-Leur, The Netherlands). Human recombinant ApoE produced in baculovirus in Sf insect cells was obtained from PanVera (Madison, WI). ApoE obtained from the conditioned medium of transfected human embryonic kidney 293 (HEK293) cells was generously provided by Dr. G. W. Rebeck (Georgetown University, Washington, DC). Affinity-purified polyclonal anti-A $\beta$ antibodies were prepared as described previously (Davis-Salinas et al., 1994). Monoclonal anti-ApoE antibody was purchased from Innogenetics (Antwerpen, Belgium). Anti-low-density lipoprotein receptor-related protein (LRP) ( $\beta$-chain) antibody was obtained from American Diagnostica (Stamford, CT). Anti-A $\beta$ antibody used for CAA grading was purchased from Dako (Glostrup, Denmark).

Cells. Pericytes were isolated from human brain tissue, and SMCs were isolated from leptomeningeal vessels from a number of $\mathrm{AD}$ patients and neurologically unaffected individuals, obtained after autopsy as described previously (Verbeek et al., 1994, 1995, 2002) (Table 1). Diagnosis and grading of $\mathrm{AD}$ patients was performed according to the criteria established by Braak and Braak (1991), Mirra et al. (1991), and The National Institute on Aging and Reagan Institute Working Group on Diagnostic Criteria for the Neuropathological Assessment of Alzheimer's Disease (1997). CAA grading was established by quantification of the number of $A \beta$-positive vessels in one microscopic field (magnification, $2.5 \times)$. At least four microscopic fields of both the occipital cortex and the gyrus temporalis medius were analyzed and categorized as follows: 0 ( - , no CAA $), 0-10(+$, sparse CAA $), 10-20(++$, moderate CAA $)$, and $>20$ $(+++$, severe CAA).

Both HBPs and SMCs were maintained in Eagle's modification of essential medium (EMEM) supplemented with 10\% human serum (Sanquin Blood Bank, Nijmegen, The Netherlands), 20\% newborn calf serum (Invitrogen, Paisley, UK), recombinant basic fibroblast growth factor (1 $\mathrm{ng} / \mathrm{ml}$ ), heparin (5 U/ml; Organon, Boxtel, The Netherlands), and antibiotics. Immunoelectron microscopical detection of $A \beta$ accumulating at the surface of cultured cells was performed as described previously (Rensink et al., 2002, 2004). With respect to the various types of experiments, we did not observe differences between cerebrovascular cell cultures with the same ApoE genotype but derived from different types of patients (i.e., $\mathrm{AD}$ or control patients).

Degeneration experiments. Triplicate wells with cultured cells were preincubated with serum-free medium (EMEM with $0.1 \%$ BSA and antibiotics) for $4 \mathrm{~h}$. Subsequently, cells were incubated with fresh serum-free medium supplemented with synthetic $\mathrm{A} \beta$ peptides at $25 \mu \mathrm{M}$ for $6 \mathrm{~d}$. Cells were routinely inspected and photographed using an Olympus (Tokyo, Japan) phase-contrast microscope. Cell viability was quantitated using a fluorescence live/dead cell assay according to the description of the manufacturer (Molecular Probes, Leiden, The Netherlands). The cultures were examined using an Olympus fluorescence microscope, and the percentage of dead cells was determined from counting in at least five microscopic fields per well. Based on previous studies (Davis and Van Nostrand, 1996; Verbeek et al., 1997), D-A $\beta_{1-40}$ was used, because this peptide induced a robust degeneration of both pericytes and SMCs.

Western blot analysis. Cells were grown in serum-free medium, and both culture supernatant and cell lysates were collected to examine secreted and cell-associated expression of proteins, respectively. Culture supernatant was diluted 1:1 with reducing sample buffer. Cells were washed twice with PBS and then solubilized in the wells with lysis buffer [50 mм Tris- $\mathrm{HCl}, 150 \mathrm{~mm} \mathrm{NaCl}, \mathrm{pH}$ 7.5, 1\% SDS, 5 mм EDTA, $500 \mu \mathrm{M}$ 4-(2-aminoethyl)benzenesulfonyl fluoride, $10 \mu \mathrm{g} / \mathrm{ml}$ leupeptine, and 10 $\mu \mathrm{g} / \mathrm{ml}$ chymostatin] for $15 \mathrm{~min}$. The protein content of diluted samples of the cell lysates was determined using the bichinchonic acid method (Pierce, Rockford, IL). Equal protein amounts were loaded, fractionated on SDS-polyacrylamide gels, and subsequently electrophoretically transferred to nitrocellulose membranes (Schleicher and Schuell, Hertogenbosch, The Netherlands) in blotting buffer ( $25 \mathrm{~mm}$ Tris-HCl, $\mathrm{pH}$ 8.6, 192 mM glycine, and 20\% methanol). Blots were washed for 15 min in PBS containing $0.05 \%$ Tween 20 (PBST), preincubated with blocking solution (5\% lowfat milk powder in PBST), washed three times with PBST, and subsequently incubated with primary antibodies and peroxidaselabeled secondary rabbit anti-mouse antibodies (Dako). Detection was performed by chemiluminescence according to the description of the manufacturer (Boehringer Mannheim, Almere, The Netherlands) and exposure to Kodak (Rochester, NY) X-OMAT-R films.

ApoE genotyping. DNA was isolated from small pieces of brain tissue, from which cell cultures were also derived, using a DNA isolation kit (Biozym, Landgraaf, The Netherlands). ApoE genotype was determined using PCR and HhaI restriction analysis according to methods described previously (Hixson and Vernier, 1990; Wenham et al., 1991).

ApoE quantification. ApoE secretion by cultured HBPs and SMCs was quantitated both by scanning of Western blots and by ELISA. The chemiluminescent signal of both ApoE standards (PanVera, Madison, WI), cell lysates, and culture supernatants obtained after Western blotting was scanned with a LabScan (Amersham Biosciences, Aylesbury, UK). For ELISA, $5 \mu \mathrm{g} / \mathrm{ml}$ affinity-purified goat anti-ApoE (Biodesign International, Saco, ME) was coated overnight at $4^{\circ} \mathrm{C}$ on a 96 -well plate. Subsequently, wells were incubated with $1 \%$ nonfat milk in PBST to block 
specific binding, with ApoE standards (PanVera, or from transfected HEK293 cells) or (diluted) culture supernatants, with affinity-purified biotinylated goat anti-ApoE (Biodesign International), and finally with peroxidase-labeled avidin (Dako). Tetramethylbenzidin was used as substrate, and $\mathrm{H}_{2} \mathrm{SO}_{4}$ was used to terminate the peroxidase reaction. No significant differences were observed with either type of standards; the use of ApoE3 as a standard only resulted in slightly higher signals than with ApoE4.

Partial purification of ApoE from culture supernatant. Purification of extracellular ApoE protein from medium of cultured HBP was performed as described by DeMattos et al. (1999) with minor modifications. Cells were incubated with serum-free EMEM medium for $6 \mathrm{~d}$. Cells remained viable during this period. Supernatant was collected and passed through a D100 weakly basic anion exchange filter (Sartorius, Goettingen, Germany) and eluted with $1 \mathrm{~m}$ ammonium bicarbonate. The eluted ApoE was recirculated over a HiTrap heparin column (Amersham Biosciences). Fractions containing ApoE were pooled and dialyzed against PBS. Using the ApoE sandwich ELISA described above and comparing the ApoE concentration with the total protein amount, it was demonstrated that, in the purified fractions, $25 \%$ of the total protein amount consisted of ApoE.

RNA isolation and Northern blot analysis. Total RNA $(8 \mu \mathrm{g})$ was isolated from cultured cells by using the RNeasy kit (Qiagen, Hilden, Germany) according to the protocol of the manufacturer. Total RNA was treated with formaldehyde (Sambrook et al., 1989), separated on a $1.5 \%$ agarose gel, and blotted onto a Hybond $\mathrm{N}^{+}$membrane (Amersham Biosciences). A 1100 bp fragment containing human ApoE3 cDNA (a kind gift from Dr. G. W. Rebeck, Georgetown University) was released from a pCMV4 expression vector by $X b a \mathrm{I}$ and $K p n \mathrm{I}$ restriction cleavage. ApoE cDNA probe was radiolabeled by ${ }^{32} \mathrm{dCTP}$ incorporation using a random-primed DNA labeling kit (Roche Diagnostics, Penzberg, Germany). After preincubation in a hybridization mix $(0.25 \mathrm{M}$ sodium phosphate buffer, pH 7.2, 7\% SDS, $1 \%$ BSA, $1 \mathrm{~mm}$ EDTA, and $0.1 \mathrm{mg} / \mathrm{ml}$ single-strand salmon sperm DNA) at $65^{\circ} \mathrm{C}$, membranes were hybridized overnight with the radiolabeled probes under the same conditions. Blots were then washed at $58^{\circ} \mathrm{C}$ with $0.25 \mathrm{M}$ sodium phosphate buffer, $\mathrm{pH} 7.2$, $1 \%$ SDS, and $1 \mathrm{~mm}$ EDTA and autoradiographed using Kodak X-OMAT-S films.

\section{Results}

HBPs and SMCs were isolated from 10 and 9 donor brains, respectively. The characterization of HBPs and SMCs has been described extensively in previous studies (Verbeek et al., 1994, 2002). The cultured cells were divided into four different groups according to their ApoE genotype: $\epsilon 2 / \epsilon 3, \epsilon 3 / \epsilon 3, \epsilon 3 / \epsilon 4$, and $\epsilon 4 / \epsilon 4$ (Table 1).

After 4-6 d of treatment with $25 \mu \mathrm{M}, \mathrm{D}-\mathrm{A} \beta_{1-40}$ cultured cells (HBPs or SMCs) lost their characteristic polygonal shape, individual cell contours became less evident, and signs of cellular atrophy were observed (data not shown). Because ApoE is codeposited with amyloid in the vessel walls in CAA, we determined whether ApoE production by perivascular cells was affected by $\mathrm{D}-\mathrm{A} \beta_{1-40}$ treatment as well. In the absence of $\mathrm{A} \beta$ treatment, both cultured SMCs and HBPs secreted considerable amounts of ApoE into the culture medium, as shown by Western blot analysis (Fig. 1). In contrast, smaller amounts of ApoE were associated with the cells. In contrast, incubation with $\mathrm{D}-\mathrm{A} \beta_{1-40}$ resulted in an inversion of ApoE distribution, with most of the ApoE remaining associated with the cells. This was confirmed by double-immunofluorescence staining of $\mathrm{D}-\mathrm{A} \beta_{1-40}$-treated cells, showing that both $\mathrm{A} \beta$ and ApoE were coassociated on the cell surface (data not shown).

These experiments suggested that an interaction occurred between the endogenously produced ApoE and the exogenously administered $\mathrm{A} \beta$ that accumulated on the cell surface (Fig. 2). Therefore, we investigated whether the ApoE genotype of the

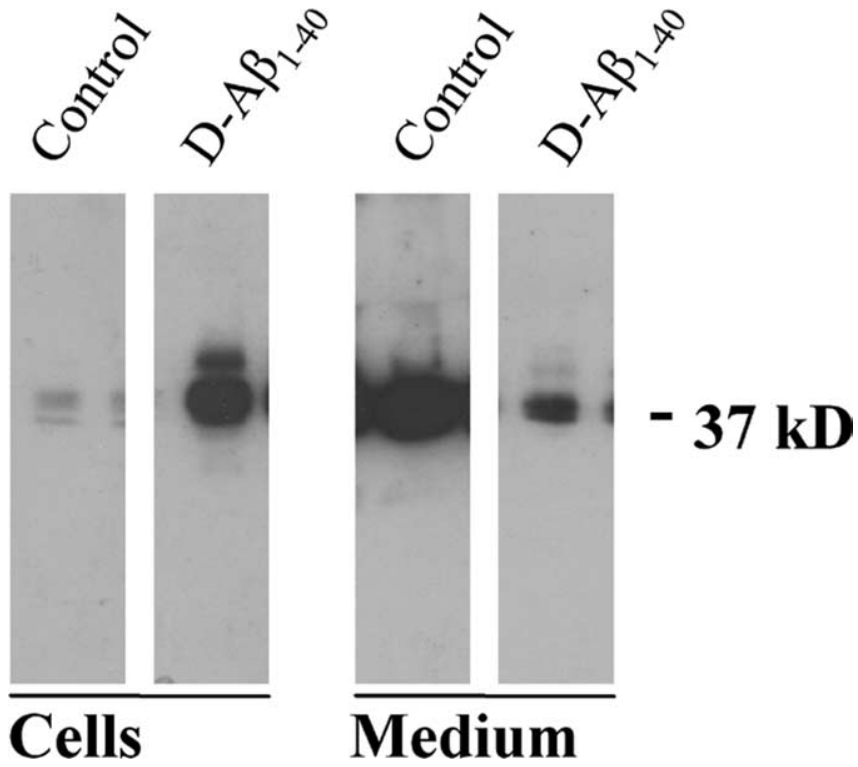

Figure 1. Western blot analysis of cell-associated (Cells) and secreted (Medium) ApoE in cultured human brain pericytes treated for $6 \mathrm{~d}$ with $25 \mu \mathrm{m} D-A \beta_{1-40}$. In untreated cultures (Control), most ApoE (molecular weight, $\sim 37 \mathrm{kDa}$ ) was present in the supernatant, whereas in $D-A \beta_{1-40}$-treated cells $\left(D-A \beta_{1-40}\right), A p 0 E$ was predominantly associated with the cellular fraction.

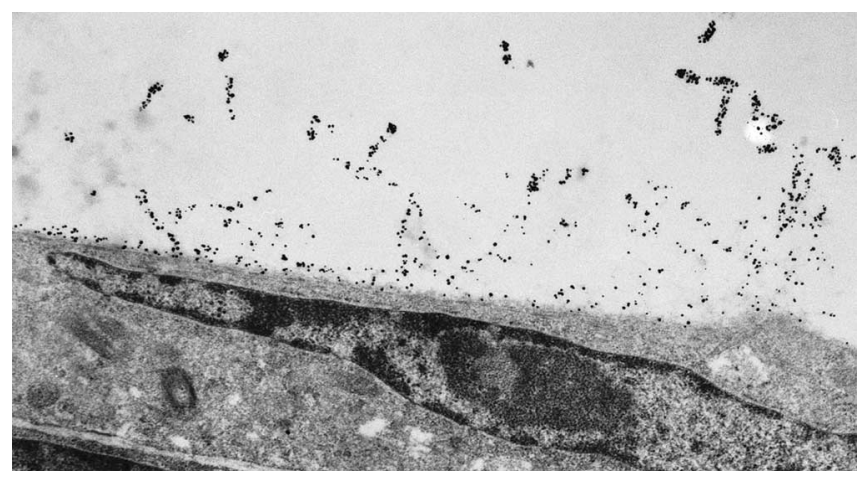

Figure 2. Immunoelectron microscopy analysis of $H B P$ for localization of $A \beta$ after $3 d$ of incubation with $D-A \beta_{1-40}(25 \mu \mathrm{m})$, showing decoration of $A \beta$ fibrils extending from the cell surface. Magnification, $6000 \times$.

cultured cells affected the toxicity of $\mathrm{D}-\mathrm{A} \beta_{1-40}$. The results showed that there were striking differences in the response to $\mathrm{D}-\mathrm{A} \beta_{1-40}$ between cell cultures with a different ApoE genotype. After treatment of HBP cultures with the $\epsilon 4 / \epsilon 4$ genotype with $\mathrm{D}-\mathrm{A} \beta_{1-40}$ for $6 \mathrm{~d}$, the number of viable cells was strongly reduced (Fig. 3). In contrast, cells with either the $\epsilon 3 / \epsilon 3$ or the $\epsilon 3 / \epsilon 4$ genotype were consistently less susceptible to $\mathrm{D}-\mathrm{A} \beta_{1-40}$ treatment. In addition, although only a single $\epsilon 2 / \epsilon 3 \mathrm{HBP}$ culture was available, we consistently observed ( $n=9$ experiments) that cell death was much lower (mean, $12 \pm 10 \%$ dead cells). In addition, similar results were obtained with SMC cultures of various ApoE genotypes (data not shown). Both HBPs and SMCs expressed the ApoE receptor LRP. The effects described above, however, could not be explained by differences in LRP expression of the cells, which was similar in the cell cultures with different ApoE genotypes (data not shown). Furthermore, the effects also could not be explained by differences in the clinicopathological state of the donors [Braak or The Consortium to Establish a Registry for Alzheimer's Disease (CERAD) grade of AD, CAA grade] (Table 1). 


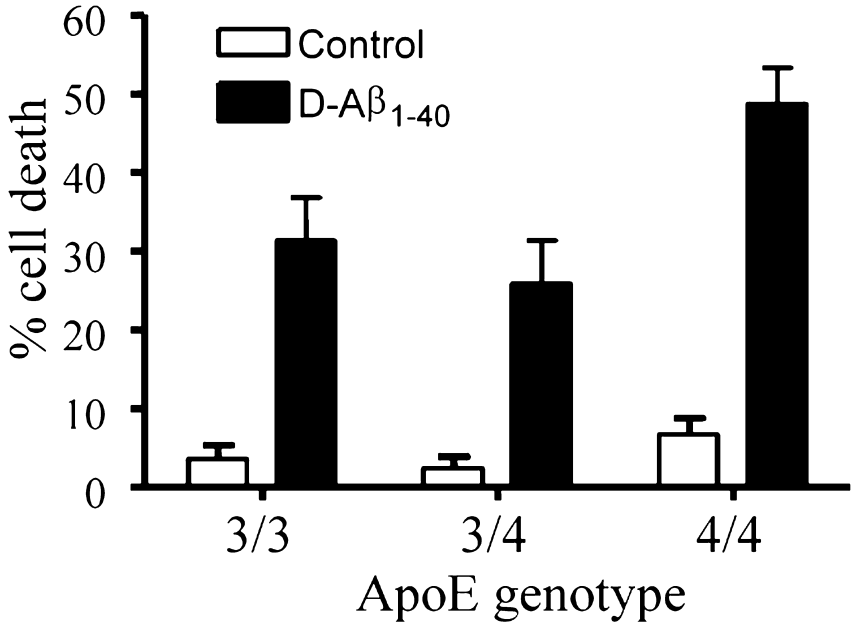

Figure 3. Comparison of the effect of treatment with $25 \mu \mathrm{m} D-A \beta_{1-40}$ for $6 \mathrm{~d}$ of human brain pericyte cultures with different ApoE genotypes. Cultured HBPs with the ApoE $\epsilon 4 / \epsilon 4$ genotype demonstrated more cell death than HBP cultures with the ApoE $\epsilon 3 / \epsilon 4$ or $\epsilon 3 / \epsilon 3$ genotype. Significance of the observed differences is as follows (ANOVA with Tukey's post hoc test for multiple comparisons): $\epsilon 4 / \epsilon 4$ versus $\epsilon 3 / \epsilon 4$ or $\epsilon 3 / \epsilon 3, p<0.001 ; \epsilon 3 / \epsilon 3$ versus $\epsilon 3 / \epsilon 4$, $p<0.05$.

These data suggested that ApoE protein modulated the association of $\mathrm{A} \beta$ with the cell surface and subsequent cellular degeneration. We therefore investigated whether simultaneous incubation of cells with $\mathrm{D}-\mathrm{A} \beta_{1-40}$ and ApoE would lead to an ApoE isoform-dependent effect on HBP death. Addition of either ApoE3 or ApoE4 (up to $1.6 \mu \mathrm{g} / \mathrm{ml}$ ), obtained from supernatants of transfected HEK293 cells, resulted in a slight but nonsignificant decrease in $\mathrm{D}-\mathrm{A} \beta_{1-40}$-induced cell death (Fig. 4 , left). The addition of any of the three ApoE isoforms (between 1.5 and 12 $\mu \mathrm{g})$ produced by baculovirus in Sf insect cells yielded a small but significant decrease in cell death of cultured HBPs (Fig. 4, middle). Remarkably, when HBP cultures were coincubated with D$\mathrm{A} \beta_{1-40}$ and conditioned supernatant of either $\epsilon 2 / \epsilon 3$ or $\epsilon 4 / \epsilon 4 \mathrm{HBP}$ cultures, a dramatic decrease in cell death was observed (Fig. 4, right). This effect was stronger when culture supernatant was used from $\epsilon 2 / \epsilon 3$ cells compared with that from $\epsilon 4 / \epsilon 4$ cells. Addition of ApoE, semipurified from conditioned HBP culture supernatants (up to $20 \mu \mathrm{l}$; containing $0.25 \mu \mathrm{g}$ of ApoE), resulted in a dose-dependent decrease in cellular toxicity (Fig. 5).

We then studied whether the differential response of HBPs with different ApoE genotypes could be explained by differences in the ApoE production capacity of the cells. ApoE production by cells with the $\epsilon 4 / \epsilon 4, \epsilon 3 / \epsilon 4$, or $\epsilon 3 / \epsilon 3$ genotype was not significantly different ( $p=0.55$; ANOVA), although we observed a trend toward lowest production by HBP $\epsilon 4 / \epsilon 4$ cultures (Fig. 6). In two of three experiments, HBP $\epsilon 4 / \epsilon 4$ cultures produced the smallest amounts of ApoE of all cultures. Interestingly, although based on only one HBP culture, cells with the ApoE $\epsilon 2 / \epsilon 3$ genotype produced a mean $5.0 \pm 3.1 \mathrm{ng}$ of ApoE per gram of protein per day ( $n=3$ experiments), which is a factor threefold to 12-fold higher than the other cell cultures ( $p=0.02$ vs ApoE $\epsilon 3 / \epsilon 3 ; p=0.21$ vs ApoE $\epsilon 3 / \epsilon 4 ; p=0.01$ vs ApoE $\epsilon 4 / \epsilon 4)$. Similar results were obtained with SMC cultures of varying genotype, with the exception of one SMC $\epsilon 3 / \epsilon 3$ culture that consistently secreted high ApoE levels comparable with that of the $\epsilon 2 / \epsilon 3$ cell cultures. In the SMC cultures, cells with the ApoE $\epsilon 2 / \epsilon 3$ genotype produced a mean $13.9 \pm 5.4 \mathrm{ng}$ of ApoE per microgram of protein per day $(n=3$ experiments), which is a factor $4-12$ higher than the other cell cultures $(p=0.01$ vs ApoE $\epsilon 3 / \epsilon 3 ; p<0.0001$ vs ApoE $\epsilon 3 / \epsilon 4 ; p=$ 0.02 vs ApoE $\epsilon 4 / \epsilon 4$; data not shown). Effects on ApoE production by the cultured cells were not correlated to differences in the clinicopathological state of the donors (Braak or CERAD grade of $\mathrm{AD}, \mathrm{CAA}$ grade) (Table 1).

Finally, ApoE mRNA levels in both HBP and SMC cultures were analyzed using Northern blot analysis. Although we did not observe a perfect match between protein secretion and mRNA levels, this analysis showed that the cells with the $\epsilon 2 / \epsilon 3$ genotype contained the highest levels of ApoE mRNA, whereas the cells with the $\epsilon 4 / \epsilon 4$ genotype contained the lowest levels (Fig. 7). There was some heterogeneity in the mRNA levels in the $\epsilon 3 / \epsilon 3$ and $\epsilon 3 / \epsilon 4$ cells. The same SMC culture with the $\epsilon 3 / \epsilon 3$ genotype that secreted large amounts of ApoE protein also contained a high level of ApoE mRNA, comparable with that in the $\epsilon 2 / \epsilon 3$ cell culture.
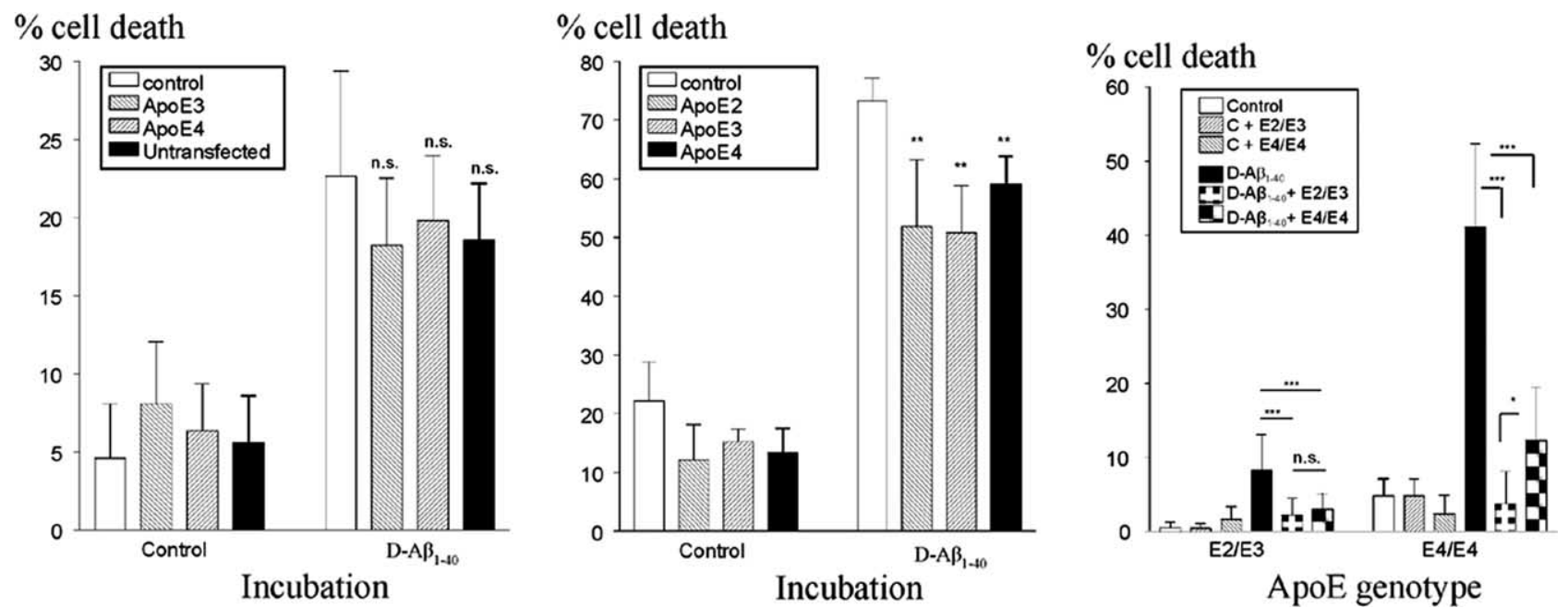

Figure 4. Effect of the presence of ApoE obtained from transfected HEK293 cells (left; $1.65 \mu \mathrm{g}$ of ApoE3/4) or produced by baculovirus in Sf insect cells (middle; $1.5 \mu \mathrm{g}$ of ApoE2/ApoE3/ApoE4) on the number of dead cells in cultures of human brain pericytes treated with $25 \mu \mathrm{m} \mathrm{D-A} \beta_{1-40}$. Addition of HEK293 ApoE3/4 did not affect the number of dead cells induced by exposure to D-A $\beta_{1-40}$ (left). Addition of any of the ApoE isoforms produced by Sf insect cells moderately, but significantly, decreased D-A $\beta_{1-40}$-induced cell death (middle). Right, Incubation with conditioned medium obtained from either $\epsilon 2 / \epsilon 3$ (E2/E3) or $\epsilon 4 / \epsilon 4$ (E4/E4) cells (indicated in the inset) significantly decreased the number of dead cells in HBP cultures with an $\epsilon 2 / \epsilon 3$ or $\epsilon 4 / \epsilon 4$ genotype (indicated on the $x$-axis). Level of significance, ${ }^{*} p<0.05 ;{ }^{* *} p<0.01$; ${ }^{* * *} p<0.001$. n.S., Not significant. 
$\%$ cell death

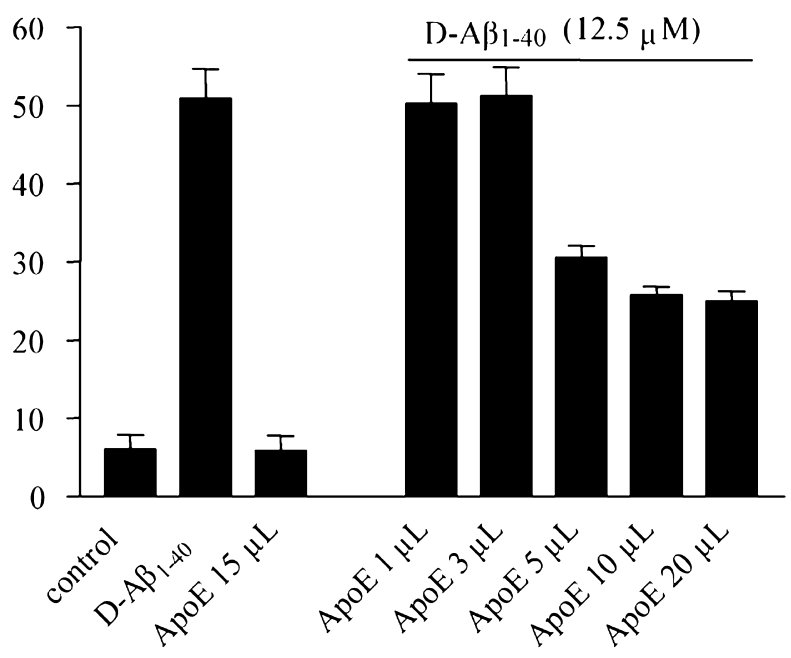

Figure 5. Addition of $A p o E$, semipurified from supernatants of cultured HBPs, reduced D$A \beta_{1-40}(12.5 \mu \mathrm{m})$-mediated HBP cell death in a concentration-dependent way.

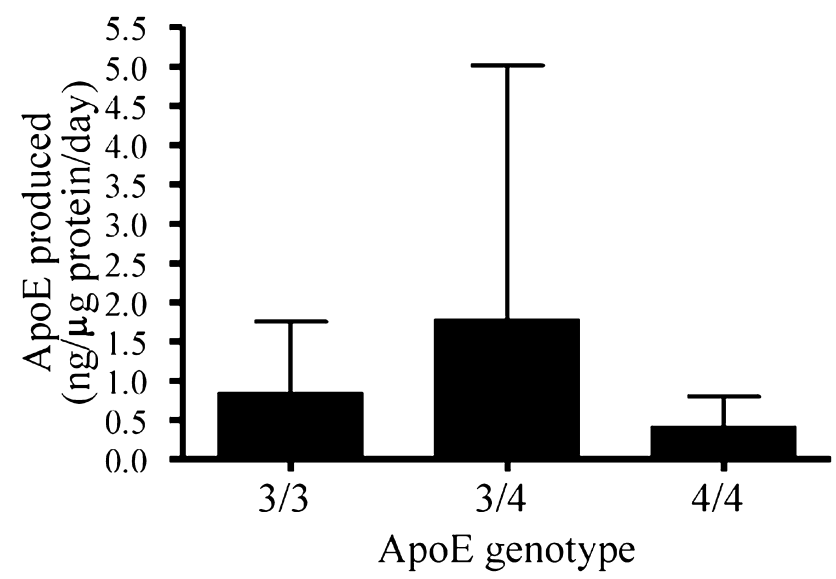

Figure 6. Quantification of $A p o E$ secretion by cultured $H B P s$ with the $A p o E \epsilon 3 / \epsilon 3, \epsilon 3 / \epsilon 4$, and $\epsilon 4 / \epsilon 4$ genotypes by ELISA. ApoE production by cells with the $\epsilon 4 / \epsilon 4, \epsilon 3 / \epsilon 4$, or $\epsilon 3 / \epsilon 3$ genotype was not significantly different ( $p=0.55$; ANOVA), although we observed a trend toward lowest production by HBP $\epsilon 4 / \epsilon 4$ cultures.

\section{Discussion}

Because of the initial reports of the association of the ApoE $\epsilon 4$ genotype with the development of $\mathrm{AD}$, many research groups have tried to identify a biological explanation for this epidemiological observation. ApoE binds to $A \beta$ and affects its fibrillogenesis, possibly in an isoform-specific manner ( $\mathrm{LaDu}$ et al., 1994; Ma et al., 1994; Wisniewski et al., 1994). In other studies, isoform-specific neurotrophic or neurotoxic effects for ApoE have been described previously (Holtzman et al., 1995; DeMattos et al., 1998; Sun et al., 1998). In the present study, we provide a novel explanation that may, in part, account for the association of ApoE with AD development. The major findings of this investigation are as follows. First, the degree of $A \beta$-mediated toxicity of human cerebrovascular cells is dependent on the ApoE genotype of the cells. Cultured HBPs with an ApoE $\epsilon 4 / \epsilon 4$ genotype were more vulnerable to $\mathrm{A} \beta$-mediated cytotoxicity than cells with other ApoE genotypes. Second, ApoE protein causes a direct, concentration-dependent inhibition of $\mathrm{A} \beta$-mediated toxicity of human cerebrovascular cells. Third, the production level of ApoE protein may, at least in part, depend on the ApoE genotype.

It has been suggested that in the brain, a balance exists between $A \beta$ deposition and $A \beta$ removal. $A \beta$ removal from the brain may occur by several mechanisms. For example, ApoE may play a role in internalization and subsequent degradation of $\mathrm{A} \beta$ and in $A \beta$ clearance via transport to the circulation. $A \beta$ may be internalized and degraded by smooth muscle cells (Urmoneit et al., 1997) and by astrocytes (Koistinaho et al., 2004), a process that is facilitated by ApoE, because astrocytes derived from ApoE $-/-$ mice do not degrade $\mathrm{A} \beta$ deposits in the brain. Alternatively, $\mathrm{A} \beta$ may be cleared from the brain via transport across the blood-brain barrier (BBB). LRP- 1 binds free $A \beta$ and possibly is the major receptor mediating $A \beta$ internalization (Urmoneit et al., 1997; Koistinaho et al., 2004) and its efflux from the brain to the circulation (Shibata et al., 2000). LRP-1 most efficiently removes wild-type $\mathrm{A} \beta_{1-40}$, whereas $\mathrm{A} \beta$ peptides containing a higher percentage of $\beta$-sheet structures (such as wild-type $\mathrm{A} \beta_{42}$ and $\mathrm{D}-\mathrm{A} \beta_{1-40}$ ) bind less efficiently, leading to accumulation of $\mathrm{A} \beta$ in brain microvessels (Deane et al., 2004). ApoE, which is also a ligand for LRP-1, may facilitate the clearance of $A \beta$ from the brain, because clearance was significantly reduced in ApoE - / - mice (Shibata et al., 2000). Therefore, it is possible that at least part of the cerebral $\mathrm{A} \beta$ forms complexes with ApoE and that such complexes via ApoE-LRP-1 interactions may be either degraded by astrocytes or cleared from the brain by transport over the BBB. However, although the existence of such complexes in the brain has been demonstrated previously (Russo et al., 1998), their possible interaction with LRP-1 has not yet been studied.

Thus, high cerebral concentrations of
A

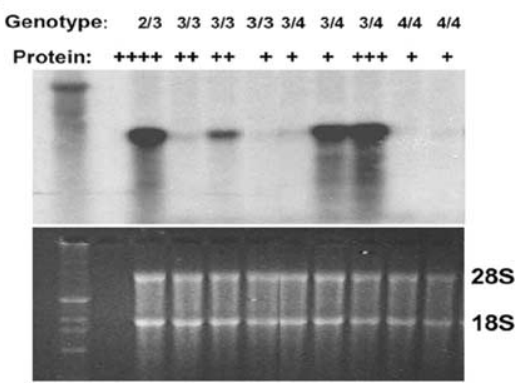

B

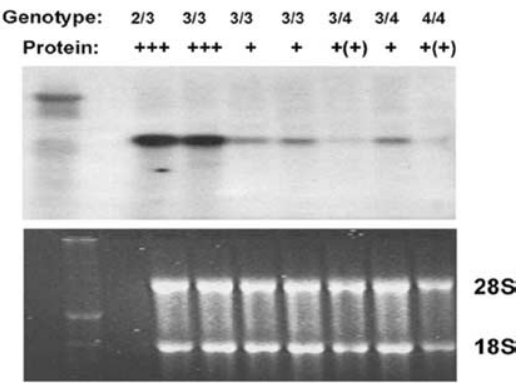

Figure 7. Northern blot analysis of ApoE mRNA expression (top) in cultured HBPs $(\boldsymbol{A})$ and SMCs $(\boldsymbol{B})$. Bottom, The levels of $28 \mathrm{~S}$ and $18 \mathrm{~S}$ RNA are shown as a control for RNA loading. ApoE mRNA expression was variable, but cells with the ApoE $\epsilon 4 / \epsilon 4$ genotype consistently contained the smallest amounts of ApoE mRNA, whereas the (single) cultures with the $\epsilon 2 / \epsilon 3$ genotype produced the highest amounts of ApoE mRNA.
ApoE may inhibit deposition of $\mathrm{A} \beta$ in the form of SPs and CAA. Our in vitro data suggest that, at least at the vascular level, ApoE abrogates the pathological interaction of $\mathrm{A} \beta$ with vascular cells and retains $\mathrm{A} \beta$ in a conformation that does not result in its assembly at the cell surface, possibly by a diminished interaction with LRP-1. These findings are in line with the observation that human ApoE, in an isoformspecific way, suppresses $A \beta$ deposition in both young and aged APP-V717F transgenic mice (Holtzman et al., 1999; Fagan et al., 2002). Furthermore, human ApoE delays the shift in $\mathrm{A} \beta$ from soluble pools to 
insoluble pools in these animals, which is in agreement with our observations of decreased accumulation of $A \beta$ at the cell surface in the presence of elevated ApoE concentrations (Fagan et al., 2002).

Thus, relatively high concentrations of cerebral ApoE are beneficial. It can be anticipated that the levels of free cerebral ApoE are reflected by its concentration in CSF. It has been reported, however, that the CSF concentration of ApoE is similar in both control and $\mathrm{AD}$ groups with different ApoE genotypes (Lehtimaki et al., 1995; Yamauchi et al., 1999), although a trend toward elevated ApoE levels in patients carrying the $\epsilon 2$ allele was observed (Lehtimaki et al., 1995). However, because the applied assays have all been designed to detect unbound ApoE, it remains possible that the levels of CSF A $\beta$-ApoE complexes will be different among individuals with different ApoE genotypes.

It has been suggested by Nicoll et al. (1997) and Greenberg et al. (1998) that both the $\epsilon 2$ and $\epsilon 4$ alleles are risk factors for CAArelated hemorrhages, the latter by increasing the vascular amyloid load and the former by increasing the susceptibility of the vessel for rupture. By incorporating these suggestions in our in vitro model, one would predict increased cell death in cells carrying the $\epsilon 2$ allele, because this would lead to vessel weakening by (A $\beta$-mediated) degeneration of SMCs or HBPs. However, our in vitro data show less cytotoxicity associated with cells possessing an $\epsilon 2$ allele. Perhaps the $\epsilon 2$ allele promotes other changes leading to vessel rupture, such as increased extracellular proteolysis.

ApoE produced by cerebrovascular cells may play a prominent role in the pathogenesis of CAA. Second only to the liver, the brain is the organ that produces the largest amount of ApoE. Astrocytes are regarded as the major source of cerebral ApoE (Boyles et al., 1985), although neurons may be able to produce ApoE as well (Xu et al., 1999). Here, we demonstrated that both pericytes and SMCs secrete ApoE and, because both are located at the abluminal side of the blood-brain barrier, they may contribute to the pool of cerebral ApoE. This may be particularly important with regard to the etiology of CAA. An attractive model explaining the pathogenesis of vascular $A \beta$ deposition has been proposed by Weller et al. (1998), who suggested that $A \beta$ of neuronal origin might be transported from the brain parenchyma to the vasculature by drainage of interstitial fluid. Experimental support for this model was provided by the transgenic mice studies by Calhoun et al. (1999), who demonstrated extensive CAA formation in APP transgenic mice under the control of the neuronal Thy-1 promotor. This model of CAA formation requires the availability of local factors that enhance or otherwise stimulate $\mathrm{A} \beta$ deposition in the vasculature. The availability of vesselderived ApoE, but possibly also factors such as heparan sulfate proteoglycans (van Horssen et al., 2001), may regulate A $\beta$ clearance and/or deposition in the vasculature. Our data suggest that when ApoE is available in high-enough concentrations, $A \beta$ may remain solubilized and be processed for clearance, whereas if $A p o E$ is available in restricted amounts only, $A \beta$ will be prone to deposition and cell-surface aggregation in the vessel wall.

The degree of lipidation of the ApoE molecule is crucial to its biological activities. Circulating ApoE is tightly bound to several classes of lipoproteins, such as high-density lipoprotein and verylow-density lipoprotein. It was demonstrated previously that lipidated and unlipidated ApoE differentially interact with $\mathrm{A} \beta$, suggesting that the degree and type of lipidation of ApoE are of critical importance (LaDu et al., 1994). In accordance with this study, we observed differences in the reduction of $\mathrm{A} \beta$-induced cellular toxicity of HBPs by ApoE, dependent on its source; ApoE, especially when secreted by HBPs, seemed very efficient. Previous studies by DeMattos et al. (1998) and Sun et al. (1998) showed that ApoE is secreted by cultured cells as specific lipid-containing particles different from those in CSF (LaDu et al., 1998). Our data suggest that between different cell types (HEK293 cells vs HBPs/ SMCs), the degree of ApoE lipidation may vary. The recombinant ApoE from PanVera is posttranslationally modified, but lipidation of the molecule is probably also different in Sf insect cells compared with HBPs.

Our comparative analysis of ApoE protein secretion and mRNA levels by the respective HBP and SMC cell cultures suggests that not only the ApoE genotype but also other unstudied factors may affect ApoE secretion (e.g., ApoE promotor polymorphisms) (Artiga et al., 1998) or factors involved in lipid metabolism. Furthermore, although we did not collect any evidence in this direction, we cannot completely exclude the possibility that the original cerebral environment of the cells (i.e., $\mathrm{AD}$, control, or other diagnosis) contributes to the cellular phenotype in vitro. Finally, future studies on other cerebral cell types will have to reveal to what extent ApoE will affect other cellular responses to $\mathrm{A} \beta$, including neuronal cell death and glial cytokine production.

\section{References}

Artiga MJ, Bullido MJ, Frank A, Sastre I, Recuero M, Garcia MA, Lendon CL, Han SW, Morris JC, Vazquez J, Goate A, Valdivieso F (1998) Risk for Alzheimer's disease correlates with transcriptional activity of the ApoE gene. Hum Mol Genet 7:1887-1892.

Bales KR, Verina T, Cummins DJ, Du Y, Dodel RC, Saura J, Fishman CE, DeLong CA, Piccardo P, Petegnief V, Ghetti B, Paul SM (1999) Apolipoprotein $\mathrm{E}$ is essential for amyloid deposition in the APP $(\mathrm{V} 717 \mathrm{~F})$ transgenic mouse model of Alzheimer's disease. Proc Natl Acad Sci USA 96:15233-15238.

Boyles JK, Pitas RE, Wilson E, Mahley RW, Taylor JM (1985) Apolipoprotein $\mathrm{E}$ associated with astrocytic glia of the central nervous system and with nonmyelinating glia of the peripheral nervous system. J Clin Invest 76:1501-1513.

Braak H, Braak E (1991) Neuropathological stageing of Alzheimer-related changes. Acta Neuropathol (Berl) 82:239-259.

Calhoun ME, Burgermeister P, Phinney AL, Stalder M, Tolnay M, Wiederhold KH, Abramowski D, Sturchler PC, Sommer B, Staufenbiel M, Jucker M (1999) Neuronal overexpression of mutant amyloid precursor protein results in prominent deposition of cerebrovascular amyloid. Proc Natl Acad Sci USA 96:14088-14093.

Corder EH, Saunders AM, Strittmatter WJ, Schmechel DE, Gaskell PC, Small GW, Roses AD, Haines JL, Pericak-Vance MA (1993) Gene dose of apolipoprotein E type 4 allele and the risk of Alzheimer's disease in late onset families. Science 261:921-923.

Corder EH, Saunders AM, Risch NJ, Strittmatter WJ, Schmechel DE, Gaskell JPC, Rimmler JB, Locke PA, Conneally PM, Schmader KE, Small GW, Roses AD, Haines JL, Pericak-Vance MA (1994) Protective effect of apolipoprotein E type 2 allele for late onset Alzheimer disease. Nat Genet 7:180-183.

Davis J, Van Nostrand WE (1996) Enhanced pathologic properties of Dutchtype mutant amyloid $\beta$-protein. Proc Natl Acad Sci USA 93:2996-3000.

Davis-Salinas J, Saporito-Irwin SM, Donovan FM, Cunningham DD, Van Nostrand WE (1994) Thrombin receptor activation induces secretion and nonamyloidogenic processing of amyloid $\beta$-protein precursor. J Biol Chem 269:22623-22627.

Davis-Salinas J, Saporito-Irwin SM, Cotman CW, Van Nostrand WE (1995) Amyloid $\beta$-protein induces its own production in cultured degenerating cerebrovascular smooth muscle cells. J Neurochem 65:931-934.

Deane R, Wu Z, Sagare A, Davis J, Du YS, Hamm K, Xu F, Parisi M, LaRue B, Hu HW, Spijkers P, Guo H, Song X, Lenting PJ, Van Nostrand WE, Zlokovic BV (2004) LRP/amyloid beta-peptide interaction mediates differential brain efflux of Abeta isoforms. Neuron 43:333-344.

DeMattos RB, Curtiss LK, Williams DL (1998) A minimally lipidated form of cell-derived apolipoprotein E exhibits isoform-specific stimulation of neurite outgrowth in the absence of exogenous lipids or lipoproteins. J Biol Chem 273:4206-4212.

DeMattos RB, Thorngate FE, Williams DL (1999) A test of the cytosolic apolipoprotein $\mathrm{E}$ hypothesis fails to detect the escape of apolipoprotein $\mathrm{E}$ from the endocytic pathway into the cytosol and shows that direct expression of apolipoprotein E in the cytosol is cytotoxic. J Neurosci 19:2464-2473. 
Fagan AM, Watson M, Parsadanian M, Bales KR, Paul SM, Holtzman DM (2002) Human and murine ApoE markedly alters A beta metabolism before and after plaque formation in a mouse model of Alzheimer's disease. Neurobiol Dis 9:305-318.

Greenberg SM, Briggs ME, Hyman BT, Kokoris GJ, Takis C, Kanter DS, Kase CS, Pessin MS (1996) Apolipoprotein E $\epsilon 4$ is associated with the presence and earlier onset of hemorrhage in cerebral amyloid angiopathy. Stroke 27:1333-1337.

Greenberg SM, Vonsattel JP, Segal AZ, Chiu RI, Clatworthy AE, Liao A, Hyman BT, Rebeck GW (1998) Association of apolipoprotein E epsilon2 and vasculopathy in cerebral amyloid angiopathy. Neurology 50:961-965

Henderson AS, Easteal S, Jorm AF, MacKinnon AJ, Korten AE, Christensen H, Croft L, Jacomb PA (1995) Apolipoprotein E allele epsilon 4, dementia, and cognitive decline in a population sample. Lancet 346:1387-1390.

Hixson JE, Vernier DT (1990) Restriction isotyping of human apolipoprotein E by gene amplification and cleavage with HhaI. J Lipid Res 31:545-548.

Holtzman DM, Pitas RE, Kilbridge J, Nathan B, Mahley RW, Bu G, Schwartz AL (1995) Low density lipoprotein receptor-related protein mediates apolipoprotein E-dependent neurite outgrowth in a central nervous system-derived neuronal cell line. Proc Natl Acad Sci USA 92:9480-9484.

Holtzman DM, Bales KR, Wu S, Bhat P, Parsadanian M, Fagan AM, Chang LK, Sun Y, Paul SM (1999) Expression of human apolipoprotein E reduces amyloid-beta deposition in a mouse model of Alzheimer's disease. J Clin Invest 103:R15-R21.

Koistinaho M, Lin S, Wu X, Esterman M, Koger D, Hanson J, Higgs R, Liu F, Malkani S, Bales KR, Paul SM (2004) Apolipoprotein E promotes astrocyte colocalization and degradation of deposited amyloid-beta peptides. Nat Med 10:719-726.

LaDu MJ, Falduto MT, Manelli AM, Reardon CA, Getz GS, Frail DE (1994) Isoform-specific binding of apolipoprotein $\mathrm{E}$ to $\beta$-amyloid. J Biol Chem 269:23403-23406.

LaDu MJ, Gilligan SM, Lukens JR, Cabana VG, Reardon CA, Van-Eldik LJ, Holtzman DM (1998) Nascent astrocyte particles differ from lipoproteins in CSF. J Neurochem 70:2070-2081.

Lehtimaki T, Pirttila T, Mehta PD, Wisniewski HM, Frey H, Nikkari T (1995) Apolipoprotein E (apoE) polymorphism and its influence on ApoE concentrations in the cerebrospinal fluid in Finnish patients with Alzheimer's disease. Hum Genet 95:39-42.

Ma J, Yee A, Brewer Jr B, Das S, Potter H (1994) Amyloid associated proteins $\alpha 1$-antichymotrypsin and apolipoprotein E promote assembly of Alzheimer $\beta$-protein into filaments. Nature 372:92-94.

Mirra SS, Heyman A, McKeel D, Sumi SM, Crain BJ, Brownlee LM, Vogel FS, Hughes JP, van Belle G, Berg L (1991) The consortium to establish a registry for Alzheimer's Disease (CERAD). Part II. Standardization of the neuropathologic assessment of Alzheimer's disease. Neurology 41:479-486.

Nicoll JAR, Burnett C, Love S, Graham DI, Dewar D, Ironside JW, Stewart J, Vinters HV (1997) High frequency of apolipoprotein E $\epsilon 2$ in patients with cerebral hemorrhage due to cerebral amyloid angiopathy. Ann Neurol 41:716-721.

Pillot T, Goethals M, Najib J, Labeur C, Lins L, Chambaz J, Brasseur R, Vandekerckhove J, Rosseneu M (1999) Beta-amyloid peptide interacts specifically with the carboxy-terminal domain of human apolipoprotein E: relevance to Alzheimer's disease. J Neurochem 72:230-237.

Premkumar DRD, Cohen DL, Hedera P, Friedland RP, Kalaria RN (1996) Apolipoprotein E- $\epsilon 4$ alleles in cerebral amyloid angiopathy and cerebrovascular pathology associated with Alzheimer's disease. Am J Pathol 148:2083-2095.

Rensink AA, Verbeek MM, Otte-Holler I, ten Donkelaar HT, de Waal RM, Kremer B (2002) Inhibition of amyloid-beta-induced cell death in human brain pericytes in vitro. Brain Res 952:111-121.

Rensink AA, Otte-Holler I, de Boer RJ, Bosch R., ten Donkelaar HJ, de Waal RMW, Verbeek MM, Kremer B (2004) Insulin inhibits amyloid $\beta$-induced cell death in cultured human brain pericytes. Neurobiol Aging 25:93-103.

Russo C, Angelini G, Dapino D, Piccini A, Piombo G, Schettini G, Chen S, Teller JK, Zaccheo D, Gambetti P, Tabaton M (1998) Opposite roles of apolipoprotein E in normal brains and in Alzheimer's disease. Proc Natl Acad Sci USA 95:15598-15602.

Sambrook J, Fritsch EF, Maniatis T (1989) Extraction, purification, and analysis of messenger RNA from eukaryotic cells. In: Molecular cloning: a laboratory manual, Chap 7.3, Ed 2. New York: Cold Spring Harbor Laboratory.
Sanan DA, Weisgraber KH, Russell SJ, Mahley RW, Huang D, Saunders A, Schemel D, Wisniewski T, Frangione B, Roses AD, Strittmatter WJ (1994) Apolipoprotein E associates with $\beta$ amyloid peptide of Alzheimer's disease to form novel monofibrils. J Clin Invest 94:860-869.

Saunders AM, Strittmatter WJ, Schmechel D, St. George-Hyslop PH, PericakVance MA, Joo SH, Rosi BL, Gusella JF, Crapper-MacLachlan DR, Alberts MJ, Hulette C, Crain B, Goldgaber D, Roses AD (1993) Association of apolipoprotein $\mathrm{E}$ allele $\epsilon 4$ with late-onset familial and sporadic Alzheimer's disease. Neurology 43:1467-1472.

Schmechel DE, Saunders AM, Strittmatter WJ, Crain BJ, Hulette CM, Joo SH, Pericak-Vance MA, Goldgaber D, Roses AD (1993) Increased amyloid $\beta$-peptide deposition in cerebral cortex as a consequence of apolipoprotein E genotype in late-onset Alzheimer disease. Proc Natl Acad Sci USA 90:9649-9653.

Shibata M, Yamada S, Kumar SR, Calero M, Bading J, Frangione B, Holtzman DM, Miller CA, Strickland DK, Ghiso J, Zlokovic BV (2000) Clearance of Alzheimer's amyloid-beta(1-40) peptide from brain by LDL receptorrelated protein-1 at the blood-brain barrier. J Clin Invest 106:1489-1499.

Strittmatter WJ, Weisgraber KH, Huang DY, Dong L-M, Salvesen GS, Pericak-Vance M, Schmechel D, Saunders AM, Goldgaber D, Roses AD (1993) Binding of human apolipoprotein E to synthetic amyloid $\beta$ peptide: isoform-specific effects and implications for late-onset Alzheimer disease. Proc Natl Acad Sci USA 90:8098-8102.

Sun Y, Wu S, Bu G, Onifade MK, Patel SN, LaDu MJ, Fagan AM, Holtzman DM (1998) Glial fibrillary acidic protein-apolipoprotein E (apoE) transgenic mice: astrocyte-specific expression and differing biological effects of astrocyte-secreted apoE3 and apoE4 lipoproteins. J Neurosci 18:3261-3272.

The National Institute on Aging and Reagan Institute Working Group on Diagnostic Criteria for the Neuropathological Assessment of Alzheimer's Disease (1997) Consensus recommendations for the postmortem diagnosis of Alzheimer's disease. Neurobiol Aging 18:S1-S2.

Urmoneit B, Prikulis I, Wihl G, D’Urso D, Frank R, Heeren J, Beisiegel U, Prior R (1997) Cerebrovascular smooth muscle cells internalize Alzheimer amyloid beta protein via a lipoprotein pathway: implications for cerebral amyloid angiopathy. Lab Invest 77:157-166.

van Horssen J, Otte-Holler I, David G, Maat-Schieman ML, van den Heuvel LP, Wesseling P, de Waal RM, Verbeek MM (2001) Heparan sulfate proteoglycan expression in cerebrovascular amyloid beta deposits in $\mathrm{Alz}$ heimer's disease and hereditary cerebral hemorrhage with amyloidosis (Dutch) brains. Acta Neuropathol (Berl) 102:604-614.

Verbeek MM, Otte-Höller I, Wesseling P, Ruiter DJ, de Waal RMW (1994) Induction of $\alpha$-smooth muscle actin expression in cultured human brain pericytes by TGF $\beta 1$. Am J Pathol 144:372-382.

Verbeek MM, Westphal JR, Ruiter DJ, de Waal RMW (1995) T lymphocyte adhesion to human brain pericytes is mediated via VLA-4/VCAM-1 interactions. J Immunol 154:5876-5884.

Verbeek MM, de Waal RMW, Schipper JJ, Van Nostrand WE (1997) Rapid degeneration of cultured human brain pericytes by amyloid $\beta$ protein. J Neurochem 68:1135-1141.

Verbeek MM, Otte-Höller I, Ruiter DJ, de Waal RMW (1999) Human brain pericytes as a model system to study the pathogenesis of cerebrovascular amyloidosis in Alzheimer's disease. Cell Mol Biol 45:37-46.

Verbeek MM, Otte-Höller I, Fransen JAM, de Waal RMW (2002) Accumulation of the amyloid beta precursor protein in multivesicular body-like organelles. J Histochem Cytochem 50:681-690.

Weller RO, Massey A, Newman TA, Hutchings M, Kuo YM, Roher AE (1998) Cerebral amyloid angiopathy: amyloid beta accumulates in putative interstitial fluid drainage pathways in Alzheimer's disease. Am J Pathol 153:725-733.

Wenham PR, Price WH, Blandell G (1991) Apolipoprotein E genotyping by one-stage PCR. Lancet 337:1158-1159.

Wisniewski T, Castaño EM, Golabek A, Vogel T, Frangione B (1994) Acceleration of Alzheimer's fibril formation by apolipoprotein $\mathrm{E}$ in vitro. Am J Pathol 145:1030-1035.

Xu PT, Gilbert JR, Qiu HL, Ervin J, Rothrock CT, Hulette C, Schmechel DE (1999) Specific regional transcription of apolipoprotein E in human brain neurons. Am J Pathol 154:601-611.

Yamauchi K, Tozuka M, Nakabayashi T, Sugano M, Hidaka H, Kondo Y, Katsuyama T (1999) Apolipoprotein E in cerebrospinal fluid: relation to phenotype and plasma apolipoprotein E concentrations. Clin Chem 45:497-504. 